N. V. Yarmolitska, PhD, Researcher Taras Shevchenko National University of Kyiv, 60, Volodymyrska Street, Kyiv, 01033, Ukraine natasha63@ukr.net

\title{
SPECIFICITY AND FEATURES OF THE DEVELOPMENT OF AESTHETICS IN THE UKRAINIAN SOVIET PHILOSOPHY IN THE 50-60s OF THE XX CENTURY
}

\begin{abstract}
The article highlights the specificity of research in the field of aesthetics in the context of the development of Soviet philosophy in Ukraine in the 50-60s. XX century. There are three main vectors of scientific work: ideological works, original aesthetic developments and historical and aesthetic research. It is revealed that ideological aesthetic works were based on the concept of "positive aesthetics" by A. Lunacharsky, which contributed to the development of the concept of socialist realism, nationality of art by Ukrainian Soviet thinkers, as well as criticism of Western aesthetics and the approval of "Soviet aesthetics". It is shown that, unlike specifically ideological works, the original aesthetic developments were aimed not at substantiating certain provisions of Marxist-Leninist philosophy, but, as far as possible, creating new concepts and ideas in this branch of philosophical knowledge. It was revealed that in the context of historical and aesthetic research, in contrast to Russian researchers, Ukrainian scientists focused mainly on the development of the national tradition. It is proved that during the period under study, aesthetic problems, along with logic, methodology of science, philosophical problems of natural science, were one of the leading in Soviet Ukraine, thereby being one of its centers throughout the Soviet Union.
\end{abstract}

Key words: Soviet philosophy, history of Ukrainian philosophy, Ukrainian aesthetics, aesthetics in Soviet Ukraine, Kyiv University, Institute of Philosophy of the Academy of Sciences of the Ukrainian SSR, Lviv-Kharkov aesthetic school.

Formulation of the problem. The development of philosophical research in Soviet Ukraine is a rather controversial phenomenon in the history of Ukrainian philosophical thought. This is especially true of the postwar period. Often, the founders of the Kiev School of Philosophy, who focused their attention primarily on logical, anthropological, philosophical and methodological issues, become the focus of scholars' attention. While other areas of philosophical knowledge, incl. ethical and aesthetic issues seemed to be "in the shadow" of the scientific developments of Ukrainian Soviet thinkers. At the same time, it should be noted that mainly scientists pay attention to either the development of aesthetics in the interwar period (N. Galan), or they analyze the work of key researchers in this area precisely in the 70-80s. (V. Ivanov, A. Kanarsky, V. Kudin, L. Levchuk, V. Mazepa).

Analysis of research and publications. It must be said that the theoretical basis of the proposed article was the fundamental monographs of I. Ivanyo [8], L. Levchuk [14] and E. Sviderski [20]. Although the focus of the first two works in separate chapters is devoted to the period we are examining in the development of Ukrainian aesthetics, they still lack a comprehensive and systematic presentation. So, in the work of I. Ivanyo, the emphasis is on works devoted to the ideological research of aesthetics, and in the monograph by L. Levchuk, there is predominantly a biographical approach to disclose this issue. As for the work of E. Sviderski, although this is the first fundamental English-language study of the phenomenon of Soviet aesthetics, Ukrainian aesthetics studios are inscribed in a general context, thereby excluding the understanding of any of its features. Another important fact is that it is often said about the "Kievcentricity" of aesthetic research in this period, thereby not considering the work of Lvov and Kharkov philosophers, who put this problem in the center of attention.

Purpose of the article. Consequently, the purpose of our article is a comprehensive and systematic study of the features of aesthetic studios in Soviet Ukraine in the 5060s. XX century.

In our opinion, it will be conceptual if we single out three vectors in the context of the corpus of aesthetic works of the period under study in the history of Ukrainian philosophy:

1) ideological aesthetic works;

2) original aesthetic designs;

3) research on the history of Ukrainian aesthetics.

Exposition of the main material of the study. Let's consider each of these research vectors in more detail below. However, according to the authors, it is necessary to say a few words about the specifics of aesthetic works in Ukraine with the emergence of Marxist-Leninist ideology, that is, about its features in the interwar period.

\section{Background:}

Aesthetic Studies in the Interwar Period.

N. Galan emphasizes: "The development of aesthetic problems by the Ukrainian philosophers of Soviet Ukraine in the 1920s-1930s took place against the background of a tense socio-political situation. The choice of the paradigm for assessing the cultural heritage of Europe and the world played a significant role in the formation of the worldview guidelines of Russian philosophers of the analyzed period. Typical for most philosophers was the way of its creative processing and a kind of "weaving" into the scope of knowledge necessary for the formation of the personality of the "new artist" and for raising the general cultural level of the Ukrainian proletarian society. Along with this, rather radical ideas functioned, which consisted in nihilistic tendencies in the formation of a new culture of the communist society, which in fact were a tribute to the postrevolutionary era" [3;128].

Therefore, as another researcher L. Martynenko writes: "Ukrainian aesthetics and art of the 1930s. $\mathrm{XX}$ century. cannot be considered in isolation from the process of implanting the cult of personality and Stalin and his repressive actions in relation to talented scientists and artists. The wave of repressions swept through Ukraine, affected all spheres of national spiritual life. The fate of M. Boychuk, M. Kulish, L. Kurbas, M. Semenko, M. Voronoi and many other repressed figures of Ukrainian culture was tragic" [7;63]. 
Hence, in our opinion, the formation and gradual development of Ukrainian aesthetic studios during the Soviet period took place in two aspects:

1) criticism of "bourgeois" concepts in Western aesthetics and respect for the authorities of MarxistLeninist philosophy;

2) contribution to the creation of "Soviet aesthetics" by publishing works on the relationship between world and proletarian culture, art and ideology, etc. questions.

\section{Ideological research in aesthetics}

First of all, it must be said that after the Second World War, in the late 40 s and early 50 s of the XXth century the critic $A$. Tripolsky was engaged in the development of certain problems of aesthetics in Soviet Ukraine. Thus, in his book "Bolshevik Party's - the Basis of Socialist Aesthetics" (1948) it is noted: "The development of the problems of the new socialist aesthetics requires serious work of philosophers, literary critics and art critics. However, reality shows that in our republic this issue is not in the center of attention of scientific and creative workers" $[1 ; 69]$.

I. Ivanyo emphasizes: "In the mid-1950s, after the 20th Congress of the CPSU (Communist Party of the Soviet Union - V.T., N.Y.), science, culture and art were further developed in all Soviet republics, including the Ukrainian SSR. The flourishing of artistic culture, the introduction of the broad masses of the working people to it, the growing role of the aesthetic principle in all areas of society's life required the solution of new creative problems. Under these conditions, the unity of science and culture is even stronger. In the activation of aesthetic research in the USSR as a whole, an important role was played by the speeches of the magazine "Voprosy filosofii" on the tasks and subject of Marxist-Leninist aesthetics (1956), as well as discussions on the topic Aesthetics and Life conducted by the "Voprosy filosofii" magazine in 61-62 years" [8; 386].

Therefore, scientists and teachers of Kyiv University, the Institute of Philosophy of the Academy of Sciences of the Ukrainian SSR, and other scientific and educational institutions on the territory of Soviet Ukraine began to actively develop ideas and concepts that would substantiate and approve a new vision of aesthetics in line with Marxist-Leninist ideology. So, in particular, one can mention such works as: "On the question of the growing role of art in the formation of the communist worldview" [15], "Communism and aesthetic education" [11], "Building communism and aesthetic education" [17], "Questions of Marxist-Leninist aesthetics in the resolutions of the Central Committee of the CPSU on literature and art" [12), "For Marxist principles in aesthetics" [5], "Aesthetics Leninism and questions of literature" [6].

Based on the texts of these works, one can see that aesthetics, as in fact, and any philosophical discipline, inevitably had to become an "instrument" and a way of implanting the party line and worldview. So, for example, in the context of aesthetic research, Ukrainian scientists considered this or that problem, concept, idea not so much to increase scientific knowledge, but to make it necessary and useful for educating people in the spirit of communist ideology.

Separately, it is necessary to mention that during the period under study, such a concept as "socialist realism" began to be actively developed. The foundation of this concept was laid by A. Lunacharsky in his work "Foundations of Positive Aesthetics" (1904), where the key aspects of Bolshevik (socialist realist) aesthetics were first systematically outlined. A rigid attitude towards the evaluative-normative nature of aesthetics, the cult of the superman and at the same time the apologetics of extreme collectivism, inhumanity - everything in Lunacharsky's positive aesthetics is directed towards the spirit and letter of the coming socialist realism [19; 36]. Therefore, in the period under study, works were published on both the concept directly given by V. Kudin $(1959,1961)$ and separately taken issues in this context, for example, B. Minchin analyzed satire in the context of socialist realism (1967), and I. Stebun tried to consider it in the context of the legacy of I. Franko (1958).

At the same time, in the spirit of the dominant ideology, it was important to substantiate and show that the very phenomenon of art is close precisely to the people. Art itself has the right to be called if it is directed to the people and has such a characteristic as a nationality. This attribute was contrasted with the massiveness of world (more precisely, Western) art. In this context, it would be appropriate to recall the works of N. Goncharenko "The problem of the nationality of literature in the MarxistLeninist aesthetics" (1968) and "The nationality of art" (1959), in which the author considered the nationality as an obligatory attribute of genuine art and everything that should have aesthetic taste. In parallel with this, criticism of Western aesthetics was actively developed during this period, which was expressed in the writing of the corresponding ideological works by Ukrainian Soviet aesthetics, in particular N. Goncharenko "Reactionary bourgeois aesthetics - the enemy of art" (1960), "Against revisionism in aesthetics" (1959).

Summing up, we can say that ideological aesthetic works were based on the concept of "positive aesthetics" by $A$. Lunacharsky, which contributed to the development of the concept of socialist realism, the nationality of art, as well as criticism of Western aesthetics and the approval of "Soviet aesthetics" by Ukrainian Soviet thinkers.

\section{Original aesthetic research}

In addition to specifically ideological works, the period under study is characterized by the appearance, as far as possible, of already fundamental aesthetic works and the development of original concepts in this branch of philosophical knowledge.

In this context, one can single out a range of key problems that Ukrainian Soviet thinkers worked on: the nature and essence of art and aesthetic, the phenomena of beauty and beauty, creativity and other aesthetic categories. Theses, which were defended, became heuristically fruitful for the further development of aesthetic thought in Ukraine:

- PhD-theses: P. Gavrilenko "Specific features of content and form in art" (1963), L. Levchuk "The role of intuition in the process of artistic creation" (1969).

- Doctor of Science-theses (Philosophy): B. Kublanov "The epistemological nature of literature and art" (1959, the first doctoral thesis in aesthetics in post-war Ukraine); V. Kudin "Aesthetics: (A course of lectures on the basics of Marx-Leninist aesthetics for the student of the humanities faculty of the university and pedagogical institute, 1962).

It seems especially important to analyze the scientific developments presented in doctoral dissertations.

The aforementioned work of B. Kublanov, the founder of the Lviv-Kharkiv aesthetic school in Soviet Ukraine, is the result of his series of monographic works, which were published by him earlier, namely "The epistemological nature of fiction" (1954), "Aesthetic feeling and art" (1956) and "The epistemological nature of literature and art" (1958). According to L. Levchuk, in his doctoral dissertation a concept is presented, which was based on an attempt to combine the aesthetic nature of art with the specifics of cognition of reality by means of art. As a result, the predicted result did not work out. In her opinion, he remained a supporter of the position that the nature of art 
can be fully explained within the framework of epistemology. This point of view was based on the recognition of scientific and artistic forms of cognition, which differ from each other only in the way of implementation: in the first case, this is a concept, and in the second, an image $[14 ; 190]$.

However, his work served in many respects to develop further discussion regarding this problem. Thus, a number of original studies by other domestic scientists arose, namely N. Goncharenko "On the essence of the new in art" [5], P. Gavrilyuk "The aesthetic nature of art" [2], V. Mazepa "Art and spiritual wealth man "[6], V. Kornienko "On the essence of aesthetic knowledge" [10]. P. Kopnin also took part in this discussion, who devoted more than one work to aesthetics.

But especially important in this regard is the subsection "Logical and aesthetic. The role of art in the movement to a new reality "in his fundamental monograph" Introduction to Marxist epistemology", in which you can see his following thought: "The peculiarity of art lies in its relation to the phenomena of reality, its role in the practical relationship between subject and object. Art not only cognizes the world, but also experiences it. Expression of a person's experiences in the process of his theoretical and practical activity is the task of artistic creativity, and in this sense it occupies a special place in the practical interaction of a subject and an object, the main form of which is labor, where the creative forces of a person, his hope, plan, goal are accumulated. To understand the essence and purpose of art and artistic activity in general means to find its place in labor, from which the future of man begins, the movement of mankind into infinity" [9; 274].

At the same time, one cannot ignore the work of $V$. Kudin, which is unique in its essence, because it is important both from a scientific point of view and from a pedagogical point of view. From a scientific point of view, this work is important, since it is the first holistic and systematic presentation of aesthetic theory in the post-war philosophical discourse of Ukraine, and from a pedagogical point of view, this book is the first textbook in Soviet Ukraine, which was necessary for students for 30 years, when already in independent Ukraine, in 1991 a textbook on this philosophical discipline was published under the editorship of $L$. Levchuk.

At this time, the concept of "laws of beauty" was also quite "actively worked out, although none of the works contains a convincing idea of their essence (one can recall P. Gavrilenko. What are the laws of beauty. K., $1966-$ V. T., N.Y), dedicated to the coverage of these laws. It is now becoming apparent that it is difficult to turn a metaphor into a law. At the same time, it should be recognized that during the formation of aesthetic science in the 50-60s, and during this period in Soviet aesthetics, many problems were developed for the first time, the hope for the formulation of the "laws of beauty" could seem quite real [13; 501].

Also in the context of understanding the phenomenon of creativity, its connection with the aesthetic during this period, it is necessary to note the works of $\mathrm{V}$. Kudin "Science and Artistic Creativity" (1969), A. Gordienko "Creative freedom and intuition of the artist" (1965), V. Antonenko "Worldview and artistic creation" (1966), V. Mazepa "Aesthetic attitude and creative idea" (1968), K. Shudri "Creative activity and aesthetic tastes" (1968). From the texts of the above works, we can say that during this period, as in general during the rule of the MarxistLeninist ideology, "aesthetics used the same methods as Soviet philosophy. She could not bring anything else. Monomethodology reigned. And we must pay tribute to the aesthetics of the time that they solved certain creative problems within the framework of monomethodology. The second aspect is that monomethodology provided an opportunity for in-depth study of what is allowed within this monomethodology" [18; 11].

Therefore, we can conclude that although original developments were developed and fundamental works were published in the studied problematic in this period, they were not devoid of Marxist-Leninist ideology. However, unlike specifically ideological works, this circle of research aimed not at substantiating certain provisions of Marxist-Leninist philosophy, but as far as possible to create new concepts and ideas in the field of aesthetics.

\section{Historical and aesthetic works}

The part of works by Ukrainian Soviet thinkers dedicated to the history of aesthetic reflections deserves special attention. L. Levchuk notes: "In Soviet times, much attention was paid to the history of aesthetic thought. Another thing is how it was written. To a lesser extent it was written in Ukraine, more in Moscow and Leningrad. But there were works on this topic in Ukraine, in particular, the doctoral dissertation of Vitaly Perederiy (Ukrainian Revolutionary Democratic Aesthetics (end XIX - beginning of XX century). - K., 1964. - V.T., N.Y). Everything was presented, so to speak, in a "narrowed" interpretation. For example, V. Perederiy's consideration of such figures as Ivan Franko or Lesya Ukrainka is reduced to their interpretation as revolutionary democrats, with a corresponding emphasis on realism as an artistic method. For example, the fact of Franco's translation of the texts of $\mathrm{K}$. Marx is noted. At the same time, things that are interesting to us today were left without attention" [18; 11].

In this context, Ukrainian scientists wrote and studies on aesthetics of famous Ukrainian thinkers and writers P. Grabowski (A. Pashkov), I. Kotlyarevsky (P. Volinsky), M. Kotsyubinsky (I. Nazarenko), P. Mirny (M. Bernshtein), G. Skovoroda (M. Redko), I. Franko (M. Parkhomenko, N. Goncharenko, I. Doroshenko, I. Stebun, K. Loiko), T. Shevchenko (I. Nazarenko) and others. It should be emphasized that in terms of volume, these works were published both in the form of scientific articles and as monographs, dissertations.

The focus of the aforementioned scholars was not so much their heritage as they tried to illuminate as fighters for communist ideals, values and principles, and those who also implicitly adhered to the main aspects of Marxist-Leninist philosophy, incl. and those moments of her aesthetics.

Hence, we can conclude that aesthetics was more developed during this period than philosophical anthropology. If reflections that at least approached philosophical and anthropological problems can only be noticed in studies from philosophical personology, which were carried out at that time by scientists from the Institute of Philosophy, Kyiv University and the Department of Philosophy of the Institute of Social Sciences in Lviv T. Bilich (1957), A. Belous (1956), A. Braginets (1956), I. Golovakhi (1953), V. Danileiko (1955), V. Evdokimenko (1955), I. Kulikov (1955), A. Lysenko (1958) and others, then aesthetics acquired purely scientific characteristics and aspects.

At the same time, already in the period under study, there was an understanding of the formation of the Ukrainian Soviet aesthetics itself. So, I. Ivanyo published a number of works, namely "Formation and development of Marxist-Leninist aesthetics in Ukraine" (1966) and "From the history of the establishment of Leninism in aesthetics in Soviet Ukraine" (1967). In these works, the author analyzed the basis of the formation of Soviet aesthetics in 
general, and in the context of the development of Ukrainian philosophy, in particular. Subsequently, these works will be included in his fundamental monograph "Essay on the Development of Aesthetic Thought in Ukraine" (1981).

In this regard, it was also important that in this period a specialized magazine began to be published, the lion's share of which was devoted to historical and aesthetic studios. This is the scientific collection Ethics and Aesthetics, which was founded in 1965 and for a long time was the only specialized journal in the Soviet Union devoted to aesthetic problems. This uniqueness contributed to the fact that at that time Ukraine had already become one of the centers for the development of this branch of philosophical knowledge, because specialists from both far and near abroad were printed in it, which contributed to even greater communication between scientists from different countries. Hence, we can conclude that by the $70 \mathrm{~s}$ of the twentieth century, Ukrainian aesthetics had become no longer closed, as it was in the pre-war period, which was embodied in the dynamic rhythm of its development in the period under study.

Conclusion. Thus, having carried out a comprehensive and systematic consideration of the development of aesthetics in the 50-60s of the XX century in Soviet Ukraine, we can draw the following conclusions:

1. In the period under study, three vectors of aesthetic developments can be distinguished: ideological works, original aesthetic works and historical and aesthetic research. Although all of them were under the influence of Marxist-Leninist philosophy, nevertheless, among them we can find original and fundamental developments that largely determined the further development of this branch of philosophical knowledge.

2. In the first decades after World War II, the development of aesthetics in Ukraine took place in different aspects: scientific, educational and publishing. Thus, in particular, doctoral dissertations in this specialty were defended for the first time, a textbook on aesthetics was published, and a separate scientific journal devoted to the investigated field of philosophy began to be published. All this indicates that by the end of the 60s. XX century aesthetics in Soviet Ukraine became one of the leading disciplines in philosophical research, along with the philosophical problems of natural science and logic.

\section{СПИСОК ВИКОРИСТАНИХ ДЖЕРЕЛ}

1. Большевик Украины. - 1951. - № 9. - 80 с

2. Гаврилюк П. І. Естетична природа мистецтва / П. І. Гаврилюк. К., 1962. -56 c.

3. Галань Н. В. Філософсько-критичний дискурс у теоретичній спадщині українських радянських фрілософів 1920-х - початку 1930-х років: Рук дис. ... канд. філософ. наук: 09.00 .05 / Н. В. Галань; наук. кер. І. М. Гоян; М-во освіти і науки України; Національний педагогічний університет імені М. П. Драгоманова. - К., 2015. - 190 с.

4. Гончаренко М. Про сутність нового в мистецтві / М. Гончаренко // Етика і естетика. - 1965. - Вип. 1. - С. 64-79.

5. Гончаренко М. В. За марксистські принципи в естетиці / М. В. Гончаренко, П. В. Копнін. - К., 1965. - 48 с.

6. Дзверін І. Естетика ленінізму і питання літератури / І. Дзверін. К.: Дніпро, 1967. - 272 с

7. Естетика: Навчальний посібник / за ред. Л. Б. Мартиненко. Умань: ФОП Жовтий О. О., 2016. - 137 с.

8. Иваньо И. Очерк развития эстетической мысли Украины И. Иваньо. - М.: Искусство, 1981. - 422 с.

9. Копнин П. В. Введение в марксистскую гносеологию (репринтное издание) / П. В. Копнин. - К.: ВПЦ "Киевский университет", 2014. $320 \mathrm{c}$.

10. Корниенко В.С. О сущности эстетического познания / В. С. Корниенко. - Изд-во Сибирского отд-ния АН СССР, 1962. - 174 с.

11. Кубланов Б. Г. Комунізм і естетичне виховання / Б. Кубланов. - Львів, 1960. - 80 с
12. Кудин В. А. Вопросы марксистско-ленинской эстетики в постановлениях ЦК КПСС о литературе и искусстве: Автореф. дис. ... канд. филос. наук / В. А. Кудин; М-во высш. образования СССР. - Киев, 1954. - 15

13. Левчук Л. Т., Панченко В. І., Оніщенко О. І., Кучерюк Д. Ю. Естетика: Підручник. За заг. ред. Л. Т. Левчук. - 3-тє вид., допов. і переробл. - К.: Центр учбової літератури, 2010. - 520 с.

14. Левчук Л. Т. Українська естетика: традиції та сучасний стан / Л. Т. Левчук. - Черкаси: Видавництво "МАКЛАУТ", 2011. - 340 с.

15. Мазепа В. І. До питання про зростаючу роль мистецтва у формуванні комуністичного світогляду / В. І. Мазепа // Етика і естетика. 1965. - Вип. 1. - С. 51-63.

16. Мазепа В.ІІ. Мистецтво і духовне багатство людини / В. Мазепа. - К.: Мистецтво, 1967. - 166 с.

17. Малишев Ю. В. Побудова комунізму і естетичне виховання / Ю. В. Малишев. - Київ, 1964. - 199 с.

18. Пролеєв С., Левчук Л. Естетика на межі епох. Бесіда головного редактора "Філософської думки" С. Пролеєва з професоркою Л. Левчук / С. Пролеєв, Л. Левчук // Філософська думка. - 2009. - № 6. - С. 5-20.

19. Силаев А. С. "Позитивная эстетика" и ее уроки (из истории литературно-эстетической мысли XX века) / А. С. Силаев // Русская филология: Вестник Харьковского национального педагогического университета имени Г. С. Сковороды. - 2017. - № 2 (61). - С. 36-41.

20. Swiderski E. The Philosophical Foundations of Soviet Aesthetics: Theories and Controversies in the Post-War Years / E. Swiderski - Springer Science \& Business Media, 2012. - 229 p.

\section{REFERENCES}

1. Bol'shevik Ukrainy. (1951). № 9 .

2. Gavriljuk, P. I. (1962). Estetichna priroda mistectva [Aesthetic nature of art]. Kyiv.

3. Galan', N. V. (2015). Filosofs'ko-kritichnij diskurs u teoretichnij spadshhini ukraïns'kih radjans'kih filosofiv 1920-h - pochatku 1930-h rokiv [Philosophical-critical discourse in the theoretical heritage of Ukrainian Soviet philosophers of the 1920s - early 1930s]. Kyiv, Nacional'nij pedagogichnij universitet imeni M. P. Dragomanova.

4. Goncharenko, M. (1965). Pro sutnist' novogo v mistectvi [About the essence of the new in art]. Etika i estetika. Vip. 1, 64-79.

5. Goncharenko, M. V. (1965). Za marksists'ki principi v estetici [For Marxist principles in aesthetics]. Kyiv.

6. Dzverin, I. (1967). Estetika leninizmu i pitannja literaturi [Aesthetics of Leninism and questions of literature]. Kyiv, Dnipro.

7. Estetika: Navchal'nij posibnik [Aesthetics: A textbook]. (2016). Uman', FOP Zhovtij O. O.

8. Ivan'o, I. (1981). Ocherk razvitija jesteticheskoj mysli Ukrainy [Essay on the development of aesthetic thought in Ukraine]. Moskow, Iskusstvo.

9. Kopnin, P. V. (2014). Vvedenie $v$ marksistskuju gnoseologiju (reprintnoe izdanie) [Introduction to Marxist epistemology (reprint edition)]. Kyiv, VPC "Kievskij universitet".

10. Kornienko, V. S. (1962). O sushhnosti jesteticheskogo poznanija [On the essence of aesthetic knowledge]. Izd-vo Sibirskogo otd-nija AN SSSR.

11. Kublanov, B. G. (1960). Komunizm i estetichne vihovannja [Communism and aesthetic education]. L'viv.

12. Kudin, V. A. (1954). Voprosy marksistsko-leninskoj jestetiki v postanovlenijah CK KPSS o literature $i$ iskusstve [Questions of MarxistLeninist aesthetics in the resolutions of the Central Committee of the CPSU on literature and art]. Kiev.

13. Levchuk, L. T., Panchenko, V. I., Onishhenko, O. I., Kucherjuk, D. Ju. (2010). Estetika: Pidruchnik [Aesthetics]. Kyiv, Centr uchbovoï literaturi.

14. Levchuk, L. T. (2011). Ukraïns'ka estetika: tradiciï ta suchasnij stan [Ukrainian aesthetics: traditions and current state]. Cherkasi: Vidavnictvo "MAKLAUT".

15. Mazepa, V. I. (1965). Do pitannja pro zrostajuchu rol' mistectva u formuvanni komunistichnogo svitogljadu [On the question of the growing role of art in shaping the communist worldview]. Etika i estetika. Vip. 1, 51-63.

16. Mazepa, V. I. (1967). Mistectvo i duhovne bagatstvo ljudini [Art and spiritual wealth of man]. Kyiv, Mistectvo.

17. Malishev, Ju. V. (1964). Pobudova komunizmu $i$ estetichne vihovannja [Construction of communism and aesthetic education]. Kiïv.

18. Prole€v, S., Levchuk, L. (2009). Estetika na mezhi epoh. Besida golovnogo redaktora "Filosofs'koï dumki" S. Prole€va z profesorkoju L. Levchuk [Aesthetics at the turn of the century. Conversation of the editorin-chief of "Philosophical Thought" S. Proleyev with professor L. Levchuk]. Filosofs'ka dumka. № 6, 5-20.

19. Silaev, A. S. (2017). "Pozitivnaja jestetika" i ee uroki (iz istorii literaturno-jesteticheskoj mysli XX veka) ["Positive aesthetics" and its lessons (from the history of literary and aesthetic thought of the XX century)]. Russkaja filologija: Vestnik Har'kovskogo nacional'nogo pedagogicheskogo universiteta imeni G. S. Skovorody, № 2 (61), 36-41.

20. Swiderski, E. (2012). The Philosophical Foundations of Soviet Aesthetics: Theories and Controversies in the Post-War Years. Springer Science \& Business Media. 
В. Е. Туренко, канд. філос. наук, мол. наук. співроб.

Н. В. Ярмоліцька, канд. фрілос. наук, наук. співроб.

Київський національний університет імені Тараса Шевченка,

вул. Володимирська, 60, м. Київ, 01033, Україна

\section{СПЕЦИФІКА Й ОСОБЛИВОСТІ РОЗВИТКУ ЕСТЕТИКИ \\ В УКРАЇНСЬКІЙ РАДЯНСЬКІЙ ФІЛОСОФІЇ 50-60-Х РОКІВ ХХ СТОЛІТТЯ}

Висвітлено специфіку досліджень у галузі естетики в контексті розвитку радянської фрілософії в Україні 50-60-х рр. ХХ ст. Виділено три основні вектори наукових робіт: суто ідеологічні праці, оригінальні естетичні розробки й історико-естетичні дослідження. Розкрито, що ідеологічні естетичні праці в основі своїй мали концепцію "позитивної естетики" А. Луначарського, що сприяла розробці українськими радянськими мислителями поняття соціалістичного реалізму, народності мистецтва, а також обґрунтовувала критику західної естетики та затвердження "радянської естетики". Показано, що, на відміну від конкретно ідеологічних робіт, оригінальні естетичні розробки ставили за мету не обґрунтування тих чи інших положень марксистсько-ленінської філософії, а, наскільки це було можливим, створення нових концепцій та ідей у цій галузі філософського знання. Виявлено, що в контексті історикоестетичних досліджень, на відміну від російських дослідників, українські вчені акцентували увагу переважно на розвитку вітчизняної традиції. Доведено, що в досліджуваний період естетична проблематика поряд з логікою, методологією науки, філософськими проблемами природознавства була однією із провідних у радянській Україні, тим самим роблячи Україну одним із центрів ії дослідження у всьому Радянському Союзі.

Ключові слова: радянська філософія, історія української філософії, українська естетика, естетика в радянській Україні, Київський університет, Інститут філософії АН УРСР, львівсько-харківська естетична школа.

В. Э. Туренко, канд. филос. наук, мл. науч. сотр.

Н. В. Ярмолицкая, канд. филос. наук, науч. сотр.

Киевский национальный университет имени Тараса Шевченко,

ул. Владимирская, 60, г. Киев, 01033, Украина

\section{СПЕЦИФИКА И ОСОБЕННОСТИ РАЗВИТИЯ ЭСТЕТИКИ}

\section{В УКРАИНСКОЙ СОВЕТСКОЙ ФИЛОСОФИИ 50-60-Х ГОДОВ ХХ ВЕКА}

Освещено специфику исследований в области эстетики в контексте развития советской философии в Украине 50-60-х г2. XX в. Выделено три основных вектора научных работ: сугубо идеологические труды, оригинальные эстетические разработки и историко-эстетические исследования. Раскрыто, что идеологические эстетические труды в основе своей имели концепцию "позитивной эстетики" А. Луначарского, которая способствовала разработке украинскими советскими мыслителями понятия социалистического реализма, народности искусства, а также обосновывала критику западной эстетики и утверждение "советской эстетики". Показано, что, в отличие от конкретно идеологических работ, оригинальные эстетические разработки ставили целью не обоснование тех или иных положений марксистско-ленинской философии, а, насколько это было возможным, создание новых концепций и идей в данной отрасли философского знания. Выявлено, что в контексте историко-эстетических исследований, в отличие от русских исследователей, украинские ученые акцентировали внимание преимущественно на развитии отечественной традиции. Доказано, что в исследуемый период эстетическая проблематика наряду с логикой, методологией науки, философскими проблемами естествознания была одной из ведущих в советской Украине, тем самым делая Украину одним из центров ее исследования во всем Советском Союзе.

Ключевые слова: советская философия, история украинской философии, украинская эстетика, эстетика в советской Украине, Киевский университет, Институт философии АН УССР, львовско-харьковская эстетическая школа.

УДК 13.02.:177:930.85

О. В. Шинкаренко, канд. філос. наук, доц. Київський національний університет імені Тараса Шевченка, вул. Володимирська, 60, м. Київ, 01033, Україна 3864301@gmail.com

\section{КУЛЬТУРА ІНДІї ЯК СВОЄРІДНИЙ ДОСВІД КУЛЬТУРНОї ІДЕНТИФІКАЦІї}

В умовах сучасної масштабної глобалізації соціокультурного буття проблема культурної ідентифікації як процесу не лише індивідуального ототожнення (ідентичності) зі світом своєї спільноти, а й колективного самовизначення у становленні та збереженні унікального культурного цілого попри загрозу розмивання значущих смислових, ціннісних, символічних орієнтацій єдності залишається нагальною для теоретичного дослідження, і культурологічного зокрема. Досвід набуття та довготривалого збереження культурної цілісності таким надскладним регіоном, як Індія, відомим своїм етнокультурним різноманіттям та складністю соціально-історичних умов існування, вважаємо досить показовим для вияву засад й умов успішності процесу ідентифікації. Статтю присвячено розгляду культурної своєрідності Індії щодо вияву притаманних її історії процесів самовизначення та збереження своєї автентичності в умовах інокультурного тиску, що залишається актуальним як для теоретичних розвідок культурної регіоналістики, так $і$ для подальших досліджень нагальної нині проблеми ідентичності й ідентифікації в їхньому культурологічному вимірі.

Ключові слова: культурна ідентифікація, культурна ідентичність, культура Індії, культурний регіон, культурні коди, культурна цілісність.

Постановка проблеми. У нинішньому полікультурному глобалізованому просторі досвід знаходження своєї культурної своєрідності, місця, ролі, можливостей розвитку, який репрезентує культура Індії, набуває особливої значущості. Загострені глобалізаційними процесами, комунікаційною об'єднаністю інформаційної мережі, проблеми співвіднесення глобального та локального ускладнюються можливістю руйнування конструктивного міжкультурного діалогу як домінуванням уніфікуючих стандартів ("давоська культура", за С. Хантінгтоном, чи "макдональдизація" (McWorld), за Б. Барбером), так і захисним заради власної культурної унікаль- ності ізоляціонізмом. На часі пошук засад і механізмів збереження балансу своєї культурної ідентичності й основних світових культурних тенденцій, модернізації зокрема. 3 огляду на це вважаємо продуктивним звернення до існуючого культурного досвіду Індії як для культурологічних досліджень проблем ідентичності та ідентифрікації, так і для культурної практики тих країн (для України зокрема), що перебувають у процесі модернізації та відродження національної самосвідомості після періоду зовнішнього соціально-культурного утиску.

Аналіз досліджень і публікацій. Культура Індії як об'єкт дослідницької цікавості привертала увагу і налі- 